\title{
10 years Equator Principles: A critical appraisal
}

\author{
Manuel Wörsdörfer
}

\begin{abstract}
June 2013 marked the formal launch of the third generation of the Equator Principles (EP III) and the tenth anniversary of the EPs - enough reasons for evaluating the EPs initiative from an economic ethics and business ethics perspective. This chapter deals with the following questions: What has been achieved so far by the EPs? Which reform steps need to be adopted to further strengthen the EPs framework? Can the EPs be regarded as a role model in the field of sustainable finance and CSR? The first part explains the term EPs and introduces the keywords related to the EPs framework. The second part summarises the main characteristics of the newly-released third generation of the EPs. The third part critically evaluates EP III from an economic ethical and business ethics perspective. The chapter concludes with a summary of the main findings.
\end{abstract}

Keywords: Equator Principles, project finance, reputational risk, corporate social responsibility, sustainable finance, multinational companies, business and human rights.

\section{Introduction}

The Equator Principles (EPs) aim for environmental protection (ie, the protection of project-affected ecosystems), the promotion of environmental and social stewardship and corporate environmental and social responsibility (CESR) - including human rights.

The EPs are officially described as a voluntary and self-regulatory finance industry benchmark in project finance. In particular, they are a finance industry standard for environmental and social risk management or, as it is often referred to, a "credit risk management framework for determining, assessing, and 
managing environmental and social risk in Project Finance transactions"1 (EPWebsite). The Equator Principles Association (EPA) refers to the Principles as the "gold standard" (Lazarus/Feldbaum 2011: i) and good practice in environmental and social risk management for project finance.

The EPs impose obligations on both lenders - the so-called Equator Principles Financial Institutions (EPFI) - and borrowers (EPFIs' clients) with regard to environmental and social impact assessment, public participation and stakeholder engagement, risk management, compliance, enforcement, and monitoring. Eg, lenders are accountable to implement responsible and sustainable lending practices. They are liable for negative social and environmental externalities of their clients. While the participating EPFIs have adopted the EPs and help enforce and monitor them, it is the client or borrower who is expected to fulfil and adhere to the laid-down requirements. These obligations are imposed by the lender upon the borrower and they are formalised as covenants that are part of the loan documentation or investment agreement between the financial institution and the project developer (cp EP 8 on Covenants).

The term Equator represents the balance between "developed" countries, "developing countries" and emerging markets, a balance between the southern and the northern hemisphere, between East and West. The EPs apply globally on both sides of the Equator. The third generation of the EPs (EP III) applies to four financial products, namely project finance, advisory services related to project finance, project-related corporate loans, and bridge loans. They apply where total project capital costs exceed US $\$ 10$ million. They are adopted by so called EPFIs, financial institutions that are active in project-finance or project-related advisory services.

\section{Equator Principles: The third generation}

The updated third generation of EPs (EP III) consists of 10 principles. $^{2}$ The first principle (Review and Categorisation) requires the EPFIs to categorise each proposed project "based on the magnitude of its potential environmental and social risks and impacts." 3 The screening process is based on the environmental and social categorisation process of the International Finance Corporation (IFC). ${ }^{4}$ Category A projects are "Projects with potential significant adverse environmental and social risks and/or impacts that are diverse, [cumulative] irreversible or unprecedented". Category B projects are "Projects with potential limited adverse

\footnotetext{
${ }^{1}$ Cp. EPA 2013b.

${ }^{2}$ Cp. EPA 2013a.

3 The following quotes refer to the third generation of the EPs (EP III): cp. EPA 2013a (pp. 5).

${ }^{4} \mathrm{Cp}$. International Finance Corporation 2012a; $2012 \mathrm{~b}$.
} 
environmental and social risks and/or impacts that are few in number, generally site-specific, largely reversible and readily addressed through mitigation measures." Category C contains "Projects with minimal or no adverse environmental and social risks and/or impacts." The categorisation process is crucial due to the decision on which environmental and social standards and procedures are subsequently applied. The following EPs apply to Category A and $\mathrm{B}$ projects only. Category $\mathrm{C}$ projects do not fall into the EPs framework since they are socially and environmentally inoffensive; they can be classified as safe from an environmental, social and human rights perspective.

Principle 2 (Environmental and Social Assessment) requires the client to conduct for all Category A and B projects an environmental and social assessment process to address all relevant environmental and social risks and impacts of the proposed project. The Environmental and Social Assessment Documentation should include "measures to minimise, mitigate, and offset adverse impacts". It should also include an Environmental and Social Impact Assessment (ESIA) and an Alternative Analysis for projects emitting more than 100,000 tons of CO2 equivalents annually. 5 For these projects, an alternatives analysis has to be conducted to evaluate less GHG-intensive technologies and procedures.

Which environmental and social standards are applicable depends on the location of the particular project. In "designated countries" - ie, mainly industrial and (high-income) OECD countries - compliance with host country laws, regulations and permits pertaining to environmental and social issues is required. In 'non-designated countries', however, compliance is also required with the IFC Performance Standards and the World Bank's EHS Guidelines (Principle 3: Applicable Environmental and Social Standards).

Principle 4 - Environmental and Social Management System and Equator Principles Action Plan - demands that the client develops and maintains an Environmental and Social Management System ${ }^{6}$ (ESMS) as well as an Environmental and Social Management Plan (ESMP). The overall aim is to comply with the applicable environmental and social standards. In case that the applicable standards are not met, the client and the EPFI will develop a joint EPAction Plan.

Principle 5 asks for an encompassing and constant stakeholder engagement process. Project-affected communities and other stakeholder groups must have rights to information, consultation and influence. Of particular importance is the "informed consultation and participation" (ICP) process, a process that ideally takes place in a "culturally appropriate manner". Information has to be readily and publicly available to the affected communities in their local languages. The

\footnotetext{
${ }^{5}$ This includes Scope 1 and Scope 2 emissions: Scope 1 emissions are direct GHG emissions from the facilities themselves while Scope 2 emissions refer to the indirect GHG emissions associated with the off-site production of energy used by the infrastructure or industry project (cp. EPA 2013a: 19).

${ }^{6} \mathrm{Cp}$. for more information on E(S)MS: Wood 2003a; 2003b; Wood/Johannson 2008.
} 
disclosure of information (eg, assessment documentation) should occur as early as possible in the assessment process - ideally within the planning stage and before construction commences - and on an ongoing basis. Project affected communities must have the right to participate in decision-making (ie, notion of Teilhabe and inclusion). Their voices have to be heard, and the interests and needs of disadvantaged and vulnerable groups taken into consideration. The whole stakeholder engagement process should be free from external manipulation, interference, coercion and intimidation. Projects with adverse impacts on indigenous peoples even require 'Free, Prior and Informed Consent' (FPIC).

The client is also required by Principle 6 to establish a (project-level and worker) grievance mechanism (as part of the ESMS), which is "designed to receive and facilitate resolution of concerns and grievances about the Project's environmental and social performance. [...] It will seek to resolve concerns promptly, using an understandable and transparent consultative process that is culturally appropriate, readily accessible, at no cost, and without retribution to the party that originated the issue or concern."

In order to assess compliance with the principles, independent monitoring, reporting, and reviewing is required. Principles 7 and 9 deal with these topics. Principle 7 requires that an independent review of the Assessment Documentation (including ESMP, ESMS and stakeholder engagement process) is conducted by an independent environmental and social expert or consultant who is not directly linked with the client. Moreover, the consultant can propose a suitable action plan for the projects that are not in compliance with the EPs. Projects which cause potential adverse impacts on indigenous peoples, critical habitats, cultural heritage, and/or involve large-scale resettlement are the most crucial ones.

Principle 9 is devoted to independent monitoring and reporting. Here, an independent consultant or a "qualified and experienced external expert" is required in order to assess project compliance with the EPs. The consultant or expert is responsible to verify monitoring and reporting information after financial close and over the life of the loan.

The Covenants-Principle 8 also deals with compliance: It requires the client to "covenant in the financing documentation to comply with all relevant host country environmental and social laws, regulations and permits." The client has the covenant to comply with the ESMP and EP-action plan, to report publicly in an appropriate format (ie, provide public reports), and to decommission facilities where applicable. Finally, "[w]here a client is not in compliance with its environmental and social covenants, the EPFI will work with the client on remedial actions to bring the Project back into compliance to the extent feasible. If the client fails to re-establish compliance within an agreed grace period, the EPFI reserves the right to exercise remedies, as considered appropriate." 7

The final principle 10 deals with accountability in the form of reporting and transparency requirements both for clients and EPFIs. The client ensures that a summary of the ESIA is made publicly available and readily accessible (eg, online

${ }^{7}$ Cp. Meyerstein 2013: 26. 
disclosure). Principle 10 also requires the client to report publicly on GHG emission levels for projects emitting more than 100,000 tons of $\mathrm{CO} 2$ equivalents annually. ${ }^{8}$ The EPFI is required to report publicly on an at least annual basis on "transactions that have reached Financial Close and on its EP-implementation processes and experience, taking into account appropriate confidentiality considerations." The EPFI is further requested to provide additional information on the total number of deals financed under the EPs, the number of Category A, B and $\mathrm{C}$ projects, the sector, region, and country of financed projects as well as information with regards to EP-implementation (ie, credit and risk management policies), independent review, role of senior management, internal preparation and (ongoing) staff-training, etc. Project names are conveyed to the EPA. Given the client's approval, this information may be made public on the EP-website in the near future.

The Governance Rules as well as the legal Disclaimer state that "the Equator Principles do not create any rights in, or liability to, any person, public or private." EPFIs adopt and implement the EPs on a voluntary, legally non-binding basis. The EP-framework is, therefore, voluntary in use relying purely on self-enforcement and the goodwill of EPFIs; no mandatory obligations or direct punitive actions can arise from the principles themselves (ie, exclusion of liability). ${ }^{9}$

\section{A critical economic-ethical evaluation}

The following paragraphs critically examine and evaluate the EPs from an economic ethics and business ethics perspective. They weigh the pros and cons and investigate what has been achieved so far and which necessary reform steps should be adopted in the near future. The main aim is to provide a baseline for a revision of EP III and pave the way towards EP IV.

8 Interestingly, the new IFC Performance Standards require annual reports for projects emitting over 25,000(!) (and not 100,000) tonnes of $\mathrm{CO} 2$ equivalent annually. The EPs' threshold is much higher than the one of the IFC Performance Standards. Thus, the EPs fall behind the commitments made by the IFC Performance Standards. "EP III does not contain any commitments on issues that are beyond what is included in the IFC Performance Standards. In some cases the commitment in EP III is even below what is required in IFC PS (such as reporting requirements on CO2 emissions)" (cp. BankTrack 2012: 8). The EPs should ideally go above and beyond the IFC Performance Standards and not fall behind.

${ }^{9}$ Cp. Andrew 2009: 306. 


\section{Limited scope of the EPs}

A major flaw of the EPs is that they only apply to project finance, bridge to project finance, project related corporate loans and project advisory. Yet, the project finance and project related corporate loans sector is a small segment for multinational financial institutions. The sector commonly accounts for up to 5 percent of the overall turnover of major multinational banks. Therefore, project finance portfolios are small and, worse, that portion is declining. ${ }^{10}$ It has become clear in recent years that multinational banks have shifted their banking activities towards the highly-profitable investment banking sector. Consequently, the EPs apply only to a small fraction of major bank's total activities. ${ }^{11}$ What is required from a business ethics perspective is a deeper engagement: The application of the EPs should be extended to other business segments and departments within a firm. The "Spirit of the Equator Principles" (Conley/Williams 2011: 547) should ideally be embedded throughout the whole company and across product categories; it should be internalised in that it is part of the core activities of multinational banks and insurance companies. What is required is outreach to neighbouring fields, with spillover to other finance areas. As a minimum requirement, the EPs should be extended to cover not only project finance, reserve-based lending and projectrelated corporate loans, but any transaction with a potential significant adverse impact on the socio-ecological environment, local communities and in particular indigenous peoples. Here, the third generation with its inclusion of project-related corporate loans and bridge loans is a major step forward to "Go Beyond Project Finance" (Lazarus/Feldbaum 2011: iii/8) ${ }^{12}$, although, it remains to examine whether this extension of scope has any practical meaning. ${ }^{13}$ A future reform of the EPs (EP IV) should include (all forms of) export finance and other forms of corporate lending and financing (including IPOs and the issuance of bonds). To put it differently: The scope of the EPs should at minimum be "extended from 'project finance' to 'financing projects"' (BankTrack 2011: 11).

\footnotetext{
${ }^{10}$ On the other hand, the still ongoing trend towards privatization of state-owned enterprises and the deregulation of state monopolies and key industry sectors (e.g., electricity and telecommunication sectors) in developing countries and emerging markets in combination with the overall trend towards globalization boost the project finance sector (cp. Scholtens/Dam 2007).

${ }^{11}$ Cp. Lazarus/Feldbaum 2011: iii.

${ }^{12}$ EP I was solely restricted to project finance. EP II included advisory services related to project finance. EP III goes one step further and incorporates projectrelated corporate loans and bridge loans. EP IV ideally extends the scope and goes beyond project finance including all forms of corporate financing, export financing, etc.

${ }^{13}$ Cp. BankTrack 2012: 8
} 


\section{Special case: The BRIC countries}

So far, a high number of BRIC countries' banks are not members of the EPA. ${ }^{14}$ Particularly the new economic powerhouses, China and India, are underrepresented. In January 2014, only one Chinese (Industrial Bank Co), one Indian (IDFC Limited), and one Russian bank (Otkritie) have joined the EPA. In particular, the major Asian players are still missing, eg, Agricultural Bank of China, Bank of China, China Construction Bank, ICICI Bank, Industrial and Commercial Bank of China (ICBC), Sberbank, State Bank of India, etc. ${ }^{15}$ China is of major importance since it is a major cross-border lender even larger than the World Bank Group. 16

In total, only five Asian banks - one Chinese, one Russian and three Japanese - are members of the EPA and represent only a tiny fraction of all EPFIs (6.4 percent); Equator banks from emerging markets represent around 25-35 percent of EPFIs (depending on the definition of emerging markets), while there is still a high concentration of Western-European, North-American and Australian EPFIs accounting for up to 65 percent of all EPFIs. ${ }^{17} 52$ out of 79 EPFIs are from industrialised countries - a heavy contrast with the regional distribution of project finance markets and the tremendous growth of project finance transactions in Asia.

The most recent financial market crisis, as well as the Eurozone crisis - have caused fundamental shifts in the global project finance markets. The share of North-American and European banks in project finance markets has dropped dramatically, due to limited liquidity, constrained risk appetite, mergers and acquisitions (by governments). As a consequence, reduced or closed project finance business activities - the share of project finance activities in emerging markets has rocketed - accounted for up to 45 percent of the market in 2012, up from 22 percent in 2008. By 2012, the top five project finance banks were all Asian.

${ }^{14}$ One noteworthy exception is Brazil. Here, 5 financial institutions joined the EPA. Another exception, although, the country is not part of the BRIC countries, is South Africa. Here, 3 financial institutions have adopted the EPs.

${ }^{15}$ Other global players which have not yet joined the EP-club are the Deutsche Bank, Morgan Stanley, and the Swiss UBS.

${ }^{16}$ Cp. Meyerstein 2013: 20.

${ }^{17}$ Most of the member institutions are from high-income OECD countries such as Australia (4 EPFIs), Canada (7), France (4), Germany (4), Spain (5), the Netherlands (6), UK (5), and the United States (5). One reason, which has already been mentioned, is that Western-European and North-American financial institutions face strong reputational pressure to become "green" and to behave in a socially responsible manner. 
Two of the top 10 project finance banks were not EPFIs, namely the State Bank of India and the Korea Development Bank. ${ }^{18}$ Moreover, most of the Chinese financial institutions displaying huge growth rates in all financial market segments are not (yet) Equator banks - which allows criticism that various nonEP-deals are carried out in BRIC countries with detrimental consequences for the environment and the people affected by project finance transactions.

One of the biggest problems in developing or emerging countries is that environmental and social governmental regulations are often inadequate. In addition, these countries face the problem of "environmental shopping" (Nwete 2005: 178): Borrowers and clients unconcerned with the environmental and social impacts of their projects can easily reduce their transaction costs by shopping the project around until they find a lender with the lowest environmental and social standards and requirements. ${ }^{19}$ If bank $\mathrm{A}$ - an EPFI - refuses to finance a particular project, non-Equator banks B, C or D might do so, and Equator bank A loses lucrative business, causing a dilemma. As a consequence of environmental shopping, environmental and social standards are circumvented and undermined. 20

This is emphasised by the geographical limitations and the missing global coverage of the EPs that threaten their de facto impact in the global project finance market. With some major project finance lenders not being part of the EPA, the playing field is not completely levelled. ${ }^{21}$ Chinese, Indian and Russian banks have the potential to undermine the whole project by financing "dirty projects", making it crucial to win them over. The status quo needs to change to prevent disadvantages for member banks, to minimise the problem of environmental shopping and to secure global socio-environmental standards, requiring a broader geographic diversification and outreach to BRIC countries. A major task of the EPA in the upcoming years is to promote the EPs in other geographical areas. 22

\footnotetext{
${ }^{18}$ Cp. Thomson Reuters 2012; Lazarus 2014.

${ }^{19}$ Cp. Hardenbrook 2007: 212.

20 The EPs as an industry-wide standard theoretically help to prevent 'environmental shopping' by creating a level playing field. The greater uniformity and commonality among project financiers make it harder for corporations to pit one financial institution against the other and to negotiate or water down environmental and social standards (cp. Hardenbrook 2007: 211). Yet, the missing global coverage and outreach to BRIC countries impedes the (entire) abolition of 'environmental shopping'.

${ }^{21}$ Cp. Lazarus 2014.

${ }^{22}$ Cp. Lazarus/Feldbaum 2011: 6; Conley/Williams 2011: 557/566.
} 
Expanding EP-membership in emerging markets and developing countries could, however, create tension ${ }^{23}$ : When more financial institutions from different regional areas, different cultural backgrounds and heterogeneous financial interests become members of the EPA, consensus building becomes increasingly difficult. The danger is that only the lowest common denominator is found (which seems already to be the case). ${ }^{24}$ One way out of the dilemma between deepening and broadening might be a tiered membership structure reflecting different aspirations. This reform proposal by Lazarus/Feldbaum is discussed later.

\section{Lack of transparency}

A major problem concerning the EPs is the lack of publicly disclosed information (ie, limited or no disclosure). Public consultation and public disclosure of information are often prevented by confidentiality duties towards clients. 25 In some cases, banks "hide behind excessive interpretations of "client confidentiality" to withhold information to stakeholders and the public" (BankTrack 2011: 5). ${ }^{26}$ It is, however, in the bank's own interest not to hide behind confidentiality issues and to be more open-minded towards stakeholder dialogue and engagement. Inclusion rather than secrecy as well as a spirit of transparency could help restore public trust in the banking sector.

Another problem related to lack of transparency is the lack of consistent reporting standards and a lack of agreed standards for audits. ${ }^{27}$. It remains to be

23 Cp. Lazarus/Feldbaum 2011: iii.

${ }^{24}$ BankTrack (2012: 4) criticises the EP III (draft) for being a "watered down compromise between parties with a widely divergent view on matters, with those Equator banks aiming for a more ambitious new 'gold standard' clearly loosing the debate from those who are fine with a little tinkering on the edges".

25 On the one hand, breaches of client confidentiality "can entail civil or criminal sanctions and damage relationship between a lender and its client" (Richardson 2005: 287). On the other hand, "NGOs have complained that this caveat [appropriate confidentiality considerations] is a hindrance to disclosure and transparency. They have found that banks are characterizing many relevant issues as "commercially sensitive" and, as such exempt from disclosure for reasons of confidentiality" (Mikadze 2012: 1406).

${ }^{26}$ Cp. Wright 2012: 64.

27 Cp. EPA 2011. 
seen whether the new reporting requirements of EP III (Principle 10) will help to overcome the lack of transparency and accountability. The EP III reporting requirements with more detailed information on the EP-portfolio (ie, detailed composition, regional and sectoral breakdown) appear to be a step in the right direction. Mandatory revelation and online disclosure of all project names and project sponsors financed under the EPs are still missing, but there will be a list of the projects financed by EPFIs on the EPA-Website to demonstrate that EPs have been applied by EPFIs. This is, however, subject to client consent. Project level disclosure has likewise been strengthened with the new EP Principle 5. Yet, (more) detailed information on the EP-implementation and compliance should be made public: Which projects were approved and which declined, and for what reasons. In the case of non-compliance, what corrective measures have been adopted to bring the project back to compliance. 28

An encompassing stakeholder dialogue and engagement process is crucial to transparency at project level. Locally-affected communities and particularly indigenous peoples should have full rights to information, consultation/ participation and influence, and full access to all relevant information. ${ }^{29}$ This is tackled by the updated Principle 5 and its "Informed Consultation and Participation" and "Free, Prior, and Informed Consent" paradigms. The challenge is how to implement it in reality. Different interpretations of what FPIC entails might prevent its full realisation. Eg, who is affected, who gives consent and what constitutes consent? For IFC consent constitutes at least the agreement of indigenous peoples to the Impact Assessment and to the Action Plan to ensure that impacts are stated correctly and actions address indigenous peoples' concerns. Currently FPIC applies only for projects impacting indigenous peoples. Should there be a universal application of FPIC to all projects? Who counts as indigenous peoples - is the definition in the IFC Performance Standards clear enough? Are their concerns adequately represented in terms of gender, age and societal structure? How many focus group consultations will be set up? Who is responsible for seeking FPIC - the state or the company? Does FPIC require a binding consultation or is an informative consultation sufficient? Does FPIC grant any veto rights (the answer is no - see below)? Does it require unanimity? If a majority is sufficient, which majority rule should be followed? Is two-thirds' majority approval sufficient for consent? Does 51-percent approval constitute consent? And what happens in cases when consent cannot be reached and thirdparty mediation fails?

Stakeholder engagement also needs to be enhanced: A structural reform in the form of a creation of an EP Advisory Group with representatives from stakeholder

${ }^{28}$ Cp. BankTrack 2011; 2012.

${ }^{29} \mathrm{Cp}$. the 1989 ILO's Convention No. 169 on Indigenous and Tribal Peoples, the 1992 Rio Declaration on the Environment and Development, the 1998 Aarhus Convention on Access to Information, Public Participation in Decision-making and Access to Justice in Environmental Matters as well as the 2007 UN Declaration on the Rights of Indigenous Peoples. 
and civil society groups and an EP Forum for engagement on finance industry sustainability issues seems promising. ${ }^{30}$ The inclusion of stakeholder groups and particularly NGOs in decision-making processes of the EPA could raise the legitimacy of the EPs and strengthen it. The feedback EPFIs will receive from the various civil society organisations will help overcome practical challenges.

\section{Lack of accountability and liability}

The Disclaimer of the EPs states that the Principles do not create any rights or liabilities, which ensures there are no mandatory obligations or direct punitive actions that can arise. The EP framework is a voluntary, legally non-binding governance system that relies on self-enforcement. Minimum entry requirements and absolute performance standards are lacking. Also lacking are clear, verifiable metrics that are transparently and independently monitored. 31

This lack of accountability occurs at an individual project (micro level), organisational (meso level) and institutional level (macro level). ${ }^{32}$ It brings negative effects on project-affected communities, local stakeholder groups as well as EPFIs: Irresponsible business activities negatively affect the organisational legitimacy of financial institutions. They might open or widen the legitimacy gap between organisational and social values respectively between current business practices and societal expectations and perceptions. In the end, they might threaten the reputational capital of a company. ${ }^{33}$. If EPFIs are truly committed to the "Spirit of the EPs" then they need to implement effective measures (including complaint and remedy mechanisms) that ensure external accountability to the public, to project-affected communities, shareholders and stakeholders.

\footnotetext{
${ }^{30}$ Cp. Lazarus/Feldbaum 2011: 10; BankTrack 2011: 10; 2012.

31 Cp. Schepers 2011: 101.

${ }^{32}$ Cp. O'Sullivan/O'Dwyer 2009: 556.

${ }^{33}$ Cp. Haack et al. 2010: 23; O’Sullivan/O’'Dwyer 2009.
} 
Some commentators even go as far as to claim third-party beneficiary rights for project-affected communities ${ }^{34}$ in order to enhance accountability and liability. These rights would allow non-signatories to a contract (ie, projectaffected communities) to enforce their rights against the contracting parties (ie, lender and borrower). A third-party beneficiary status would provide a right to a promised performance enforceable by a non-signatory to a contract. This approach proposed by $\mathrm{Marco}^{35}$ would hold both borrowers and lenders accountable for failing to adhere to the EPs. Borrowers and lenders as promisors owe duties of performance to project-affected communities as local stakeholders, that, if breached are enforceable by the respective communities. EPFIs and clients that violate the EPs could be sued ${ }^{36}$ : Project-affected communities would be able to assert their third-party beneficiary rights through breach of contract actions in US $^{37}$, Canadian 38 or European courts. The overall aim is to curb negative

34 The Alien Tort Claims Act in the United States allows US-American companies to be sued by foreigners from the host country in US courts for torts committed abroad. Domestic courts become increasingly aware of human rights abuses committed on foreign soil and the need to grant legal standing for the victims. More and more litigations are brought before domestic courts for distant human rights violations, perpetrated by governments or private actors such as multinational companies (cp. Imai et al. 2007: 137; Imai et al. 2012; Zumbansen 2004; 2005; 2006).

${ }^{35}$ Cp. Marco 2011.

${ }^{36}$ If a lawsuit could be brought against an EPFI for violating the EPs, this would have significant consequences: EPFIs would have an increased incentive to strictly screen and monitor financed projects in order to avoid lawsuits (as well as the fines for violating environmental and social laws, the court fees for defending against these lawsuits, and the damage to the brand reputation). Yet, this possibility would also create a large disincentive for other banks to join the EPA, and already members of the EPs could leave the Association to avoid being sued (cp. Hardenbrook 2007: 218). Nevertheless, accountability, liability and transparency are indispensable aspects of an effective governance regime: Global environmental, social and human rights standards can only be established and effectively monitored when the relevant actors can be held accountable for their practices. Moreover, third-party beneficiary rights and the possibility of lawsuits could also help to separate free-riders that are merely interested in gaining reputational benefits from those EPFIs that are truly committed to the 'Spirit of the EPs'.

${ }^{37}$ Cp. the 1789 US-Alien Tort Statue/Alien Tort Claims Act: "The district courts shall have original jurisdiction of any civil action by an alien for a tort only, committed in violation of the law of nations or a treaty of the United States" (28 U.S.C. $§ 1350)$. 
environmental and social impacts on local communities and to ensure that projectaffected communities and indigenous peoples maintain their livelihoods. 39

\section{Inadequate monitoring}

So far, EP compliance relies mainly on passive or interactive monitoring. 40 NGOs, civil society organisations, and other stakeholder groups function as watchdogs. ${ }^{41}$ In case of apparent non-compliance - ie, corporate governance scandals and serious violations of environmental, social and human rights standards - NGOs might start public naming and shaming campaigns. These protests often catch media attention and as a consequence might create negative publicity for the involved EPFIs and their clients. In fact, most of the founding members of the EPs have been targeted by NGO criticism and civil society organisations' advocacy campaigns. Therefore, it is in the EPFIs own best interest to take preventative measures and to boost their credibility and reputation relative to critics. To avoid reputational threats, an active and "internal" form of monitoring is required. A mandatory, independent and transparent third-party assessment of compliance - eg, in the form of an independent EP-ombudsman 42 is needed (Principles 7 and 9 deal with these particular requirements. It remains to be seen whether they are able to establish a properly working independent review and monitoring system). This impartial verification of conformity should be based on absolute performance standards as well as clear, verifiable metrics that are transparently monitored - both missing from the third generation of the EPs. Finally, official and joint project-level grievance mechanisms as well as thirdparty complaint (and dispute settlement) mechanisms 43 at the corporate or

38 Cp. Supreme Court of Canada 2013.

${ }^{39}$ Cp. Marco 2011; Hardenbrook 2007: 218.

40 Cp. Sarro 2012: 1542.

${ }^{41}$ Cp. O'Sullivan/O'Dwyer 2009.

42 The IFC has already established an ombudsman and compliance officer; $\mathrm{cp}$. IFC Compliance Advisor Ombudsman 2013.

${ }^{43}$ These third-party complaint mechanisms on the associational level could complement client's project-level grievance mechanisms. These mechanisms ideally help to enhance corporate credibility and reputation by fostering lender and client compliance. They also help to overcome the problem of free-riding (due to the fact that the detection of free-riding and cheating is more likely) and help to avoid collective-action problems (among EPFIs and within the EPA) and 
industry-level are needed to address inadequate implementation and noncompliance. These compliance mechanisms should conform to the principles of legitimacy, accessibility, predictability, equitability, rights-compatibility, and transparency. It is important to examine whether Principle 6 of the third generation of EPs might be able to establish effective and efficient project-level grievance and complaint mechanisms.

\section{Lack of implementation and enforcement}

The EPs are a set of voluntary guidelines without appropriate accountability, monitoring and auditing systems. The self-regulatory regime is ineffective since a credible deterrent, an "enforcement pyramid" (including delisting 44 and exclusion of non-compliant EPFIs) and formal sanctions are absent (cp paragraph 8 on sanctions). Loopholes, grey areas and a discretionary leeway also exist to circumvent the Principles in myriad ways (cp paragraph 9 on exit-door strategies).

The lack of committed resources to the implementation of the Principles by the respective EPFIs is also a problem. The EPs need to be embedded throughout the whole organisation. All levels of an organisation should internalise the spirit of the EPs. Some of the important factors are environmental and social management systems, environmental and social risk management, monitoring and auditing systems as well as due diligence. Environmental and social risk management as well as CSR due diligence should ideally be integrated into the company's core businesses. Recruitment, outside consultation, staff and front-line training as well as awareness rising and sensitising are essential, as is top-level commitment: The $\mathrm{CEO}$ and other senior managers function as role-models. A change in organisational culture also affects the incentive structures and in particular the bonus payment systems that should be long- rather than short-term oriented. Additionally, it is required to enhance funding and staffing of the EPA (ie, reform of the EPA). The currently available financial and personnel resources are insufficient to guarantee proper assistance and advice to implement the Principles and to effectively monitor compliance with standards. ${ }^{45}$

principle-agent problems (between lenders (EPFIs as principals) and sponsors/clients (as agents)). Interestingly, EPFIs play a double role: they function as self-regulators and regulators: the EPs regulate Equator banks (being part of the regulating EPA) as well as EPFIs' clients via loan documentation and covenants (i.e., hierarchical relationship) (cp. Flohr 2014).

${ }^{44}$ So far, a de-listing is possible according to the EPA-Governance Rules, if an EPFI fails to report publicly within 18 months or if it does not pay the annual fee. Only in these cases will an EPFI be removed from the list and, thus, be no longer a member of the EPA (a re-adoption, however, is still possible). Yet, it is not planned to de-list a company due to non-compliance.

${ }^{45}$ Cp. Lazarus/Feldbaum 2011: iii 


\section{Practical failure}

EPFIs are still financing controversial projects, particularly in developing countries where investors try to maximise profits while shirking contractual responsibilities (covenants) in project-affected communities. ${ }^{46}$ The funding of "dirty projects" continues. 47 Some of the most controversial projects include large-scale oil and gas projects (eg, in the Arctic) and massive fossil fuel projects particularly those emitting GHG. ${ }^{48}$ The aim of EP III is to limit GHG emissions and, in general, negative externalities of project finance. The EPA should reconsider whether significantly high emitting projects succeeding a certain threshold should be automatically excluded from financing. So far, a categorical exclusion of projects and business activities with a high impact on climate change/global warming does not exist.

A further problem concerns the financing of nuclear power plants, which are, from an environmental perspective, highly destructive and unsustainable (ie, the problem of finding an adequate permanent repository site for nuclear waste), leaving aside the inherent risks and dangers of nuclear energy.

\footnotetext{
${ }^{46}$ Cp. Marco 2011: 453.

${ }^{47}$ Dirty projects are those projects that involve one or more of the following socioenvironmental and human rights standards violations: environmental degradation; community health risks; destruction of community livelihoods, especially those of indigenous peoples; forced resettlements and displacements; forced labour/child labour; poor working conditions/violation of labour rights; unfair terms of employment; trade union intimidation and suppression; discrimination due to gender, race, nationality, ethnicity, religion, disability, age or sexual orientation; use of coercion, intimidation and violence; obstruction of justice and intimidation of the free press; production of and trade with illegal and/or controversial weapons; trade with countries that abuse human rights; pervasive tax noncompliance; speculative investments, especially investments in food commodities; corruption, bribery and fraud; contribution to war crimes; collaboration with security forces/paramilitary groups; and human rights violations committed by subsidiaries and (sub-)contractors along the labour and supply chain. By providing financial support to their clients (i.e., provision of corporate loans as well as managing, underwriting and/or assisting with the issuance of shares and bonds; financial institutions (FI) are also significant shareholders in many of the companies), FIs tacitly condone, promote and profit from the controversial business operations of their business partners - some of these harmful investments contribute directly to serious breaches of human rights, social and environmental regulation. FIs, thus, play a key role in determining the future existence of the aforementioned detrimental business practices: Through their investment and business decisions, they co-determine whether or not financial resources are used in an ethical and sustainable manner (cp. Facing Finance 2012; 2013: 4).
}

${ }^{48}$ Cp. BankTrack 2011: 13; 2012: 10. 
In summary, non-compliance continues. The EPs are still violated in practice on both sides. Both borrowers and lenders fail to implement the EPs in practice. Reasons for EP-breaches are the failure of an enforcement mechanism, the lack of formal sanctions, the lack of objective and verifiable metrics to measure performance, a lack of transparent monitoring, and last not least, an inconsistent EP-implementation: The latter should be overcome by facilitating knowledge transfer, information sharing, and membership capacity building especially via the EPA. The website/intranet of the EPA is the ideal place to provide all EPFIs with case studies, training materials, guidelines, implementation tools and resources. Best practice workshops and regional workshops should be organised to help EPFIs with implementation. 49

\section{Sanctions}

Monitoring, enforcement, and sanctions form an indissoluble triangle. In all three regards, the EPs lack proper governance mechanisms. With regards to sanctions, do the EPs have enough bite to penalise institutions that fall behind their voluntary commitments? Currently, EPFIs face few sanctions should they not comply with EP-governance structures. So far, only public naming and shaming campaigns that cause media attention put EPFIs and their clients under pressure. 50 Especially NGOs functioning as watchdogs have a powerful position when it comes to reputational pressure. They help to ensure that non-state actors such as multinational companies abide by their voluntary commitments and guidelines (e.g., corporate human rights responsibility, responsibility for sustainable development and environmental stewardship). Nevertheless, this passive and expost way of monitoring is not sufficient to prevent non-compliance. What is needed is the establishment of a credible deterrent and an 'enforcement pyramid'. This pyramid should start with less coercive means such as an appeal to lender's and client's environmental and social responsibilities, warnings and deadlines for bringing projects back into compliance. Only when these fail, should more coercive tactics such as formal sanctions and fines be employed. The final stage of such an enforcement pyramid should include the delisting of non-compliant institutions and an exclusion of EPFIs not meeting the standards. 51

49 Cp. Lazarus/Feldbaum 2011: 8 .

${ }^{50} \mathrm{Cp}$. Lee 2008: 362.

${ }^{51} \mathrm{Cp}$. Sarro 2012: 1549. 


\section{Exit-door strategies}

The EPs are vaguely, even ambiguously, formulated leaving enough discretionary leeway for diverging interpretations. The language used is often declaratory rather than compulsory; some principles are conditional in nature, others contain mere recommendations. Words such as "should", "intend", "aim", "encourage" 52 , "make aware of", "commit" are used, while legal terminology such as "shall", "must", "will", "oblige" is more or less avoided. The EPs are written in "should" not in "shall" language, which implies no legal obligations. Loopholes and grey areas also exist. 53 Borrowers and lenders are able to circumvent the contractual obligations of the EPs to avoid being classified as high risk. 54 Banks can redefine their project finance activities as representing something else, such as corporate or export finance and project financiers take the backdoor option and classify their projects as category $\mathrm{B}$ or $\mathrm{C}$ to avoid a stricter $\mathrm{A}$ classification. 55

\section{Adoption motives 56}

NGOs accuse EPFIs of green washing and window dressing 57: An often heard criticism is that the EP-engagement is just a PR exercise (ie, CSR as a mere

\footnotetext{
${ }^{52}$ What happens if 'encouraging' and 'awareness rising' do not lead to anything? Which sanctions do exist?

${ }^{53}$ E.g., the alternatives analysis requires "the evaluation of technically(!) and(!) financially feasible and cost-effective(!) options" leaving enough discretionary leeway for the involved EPFIs and their clients.

${ }^{54}$ Cp. Marco 2011: 470.

${ }^{55}$ Cp. Haack et al. 2010: 21; Wright 2012: 68.

56 The main motives for financial institutions to adopt the EPs include the following ones: 1 . Level the playing field; 2 . managing financial risks/credit risk mitigation; 3. reputational risk management/managing non-financial risks. Beside these economic and self-interested rationales for EP-adoption (i.e., EPFIs are regarded as private profit seeking entities that try to minimise financial, legislative and reputational risks and/or try to follow a differentiation-based strategy that allows them to achieve competitive advantages), altruistic motives also seem to play a (minor) role: Among them are good corporate citizenship, environmental consciousness, public goods preferences (i.e., CSR and environmental protection/sustainability as public goods), social preferences or warm-glow preferences of employees, investors and consumers, etc. (cp. Chan 2012; Conley/Williams 2011: 550; Kulkarni 2010; Macve/Chen 2010: 894).
} 
rhetoric device). Multinational banks, so the argument goes, are merely interested in the branding benefits and the increased reputational capital. Their main aim is to avoid naming and shaming campaigns, negative media coverage and public criticism that might threaten banks' reputational capital. As such, adopting the EPs is just seen as a precautionary measure against the potential threat of public outcry and a form of managing non-financial risk (eg, reputational risk management). Response to socio-political stakeholder pressure is seen here as the main motive behind the adoption of the Principles, mainly motivated by strategic reasons rather than intrinsic motives.

Others criticise that the EPFIs aim to avoid mandatory and formal, state-run regulations and the costs accompanied with this potential future regulatory compliance. Firms use the freedom of self-regulation to pre-empt governmental regulations. By adopting the EPs, they can decrease this threat of potential regulation and the accompanied compliance costs.

The EPs are also criticised for their symbolic nature (ie, 'economy of symbolism'): According to that, the EPs are a mere symbolic gesture leaving enough flexibility and discretionary leeway as well as a minimal appeasement strategy aiming to appease NGOs and other stakeholder groups. 58

It is almost impossible to figure out the particular and concrete motives of EPFIs that made them adopt the EPs - most likely, it is an interdependent mixture of financial and non-financial rationales. Yet, it is clear that the adoption process has to be followed by an adequate embedding and implementation process. The spirit of the EPs has to be internalised, otherwise, they remain a paper tiger (ie, high-minded commitments on paper that fail to be enforced in practice ${ }^{59}$ ) and a corporate PR-tool for green-washing and window dressing purposes only. In case that the EPs are (at least partially) backed by an intrinsic motivation (among other motives), voluntary codes of conduct such as the EPs can serve as signalling devices that demonstrate positive (ethical or green) credentials. They help to communicate environmental and business ethics commitments to external stakeholders with the aim to strengthen corporate reputation and organisational legitimacy. ${ }^{60}$ In case that intrinsic motivation is lacking, the danger comes up that

${ }^{57} \mathrm{Cp}$. for an opposing view: Scholtens/Dam 2007: 1308: "We do not find support for the view that adoption of the Equator Principles is merely window dressing, since there are at least some costs involved" (e.g., larger operational, screening, and implementation costs; EP-compliance might also lead to a delay in project completion due to the time-consuming requirements). The costs, however, might be outweighed by the potential benefits of signing up (e.g., reduced reputational risk/better reputation, positive impact on (financial) risk profile, better market access, charging of premium prices, enhanced possibilities to recruit high quality employees, etc.).

${ }^{58}$ Cp. O’Sullivan/O’Dwyer 2009: 566.

59 Due to a lack of adequate enforcement, monitoring and sanctioning mechanisms, the EPs (in its current version) seem to exist only on paper.

${ }^{60}$ Cp. Wright/Rwabizambuga 2006: 90; O’Sullivan/O’Dwyer 2009. 
environmentalism is a 'rich man's game', ie, compliance with environmental and social standards is only ensured in economically prosperous times. Thus, it is rather unlikely that voluntary codes of ethics will succeed in a weak economic climate. If this would be the case, then the future of the EPs would depend on the state of the global economy. 61

\section{Free-riding and adverse selection}

The motives behind the adoption of the EPs bring us to our next point of criticism - the problem of freeriding and adverse selection 62 . EPFIs know that they potentially gain reputational benefits irrespective of their actual practices. Even EPFIs that do not intend to comply gain good publicity from their association with the EPs. They imitate or mimic the behaviour of good EPFIs, while projectaffected communities suffer from a lack of effectiveness and practical failure of the EPs. In other words: Irresponsible institutions might claim benefits of enhanced reputation and a reduced threat of government regulations with no intention of actually implementing their new commitments. 63 Strategic freeriders gain the benefits without bearing the implementation and compliance costs. The danger, therefore, comes up of attracting signatories that are not truly committed to the spirit of the EPs. Freeriding behaviour leads to competitive disadvantages for adopters, since they have to bear compliance costs while free-riding companies do not. Additionally, freeriding negatively affects the collective by lowering the standards of the code and by decreasing the level of compliance. In the end, the brand value of the EPs diminishes. 64

One proposed solution to overcome the problem of freeriding and adverse selection is to introduce entry criteria for the EP membership and absolute performance standards. Moreover, a two-tiered EPA membership structure 65

${ }^{61} \mathrm{Cp}$. Conley/Williams 2011: 564.

62 "Adverse selection results from corporations joining the collective, gaining the benefits of the collective, while at the same time negatively affecting the collective by lowering the standards of the code [...]. As the number of adoptees increases, the newer members are more likely attracted by the benefits while at the same time decreasing the level of compliance. Adverse selection reduces the incentive of strong performers to join or remain as members" (Schepers 2011: 94).

${ }^{63}$ Cp. Wright/Rwabizambuga 2006: 91; Macve/Chen 2010: 895; Schepers 2011: 93.

${ }^{64}$ Cp. Sarro 2012: 1532.

${ }^{65}$ Such a two-tiered membership structure is de facto already in place. The so called Thun Group of Banks consisting of seven leading international banks 
reflecting different aspirations would allow EPFIs to voluntarily apply the spirit of the EPs to fields other than project finance, thus moving beyond project finance. This European Union-like "two speed" or "clubs within the club" structure would allow EPFIs to proactively respond to ethical and environmental issues and meet the demands of multiple stakeholder groups. EPFIs would have the strategic opportunity to "over-comply" (Kulkarni), to go beyond what is formally/legally and informally required and gain first-mover advantages. They might boost their credibility and as a consequence gain (additional) reputational capital that directly adds to their brand value. In case that the spirit of the EPs is internalised and embedded throughout the whole organisation, this could also trigger a cultural change within banks and other financial institutions.

While a tiered membership structure once established would allow EPFIs to voluntarily comply with additional and strengthened environmental, social and human rights standards that go beyond the IFC Performance Standards, it would at the same time take into consideration that some EPFIs are not willing or able to comply with the respective strengthened standards (and to bear additional implementation and compliance costs). Nevertheless, these EPFIs would still be part of the EPA. This would ensure that at least minimum environmental, social and human rights standards are met (given that adequate monitoring and sanctioning mechanisms are established).

A tiered membership structure is particularly important when considering the rising tension between a broadening (ie, outreach to BRIC countries) and a deepening strategy (ie, further enhancement and strengthening of the Principles): The decision-making process is already slow and complicated given the conflicting views and differing priorities especially between EFPIs from high income OECD countries and those from "non-designated countries". The more financial institutions coming from heterogeneous cultural backgrounds and having (partially) conflicting interests adopt the EPs, the more difficult consensusbuilding within the EPA gets. In several occasions in the recent past (cp the most recent review and update process), only the lowest common denominator could be

(Barclays, BBVA, Credit Suisse, ING Bank, RBS Group, UBS and UniCredit) recently published a working paper on banks and human rights (cp. Thun Group 2013). The paper is the result of two years of deliberations among the Thun Group members and provides a (first) guide to the banking sector for operationalizing the UN Guiding Principles on Business and Human Rights. The paper recognises that the UN Guiding Principles apply to all parts of a bank's business segments, including asset management, corporate and investment banking. The paper has been welcomed by BankTrack as a significant step towards recognizing the relevance of human rights to banks' core business (cp. BankTrack 2013); yet, the paper has also been criticised for its limited scope: the main problem is that it focuses solely on Principles 16-21 of the UN Guiding Principles (which are related to the corporate responsibility to respect human rights) leaving aside the foundational principles $11-15$ as well as all those principles devoted to operational-level grievance, complaint and remedy mechanisms (cp. Principles 22 and 29 of the UN Guiding Principles). 
found. This process of consensus-seeking with all its negotiations and bargaining is not only time-consuming and slow, it also inhibits the further advancement of the EPs in general.

\section{Business and human rights}

The EPs explicitly acknowledge John Ruggie's Protect, Respect, and RemedyFramework (PRR), which forms the basis of the United Nations' Guiding Principles on Business and Human Rights. 66 They also acknowledge the Universal Declaration of Human Rights, the International Covenants on Civil and Political Rights, and on Economic, Social and Cultural Rights, the core conventions of the International Labor Organization, and the UN Declaration on the Rights of Indigenous Peoples.

Human rights are closely related and interlinked with the inclusion of projectaffected communities, particularly indigenous peoples, but also NGOs, civil society organisations and other local stakeholder groups. It is the aim of the EPs to establish an ongoing and culturally appropriate stakeholder engagement and informed consultation and participation process. Information has to be made readily and publicly available to the project-affected communities in their local languages. 67 The disclosure of information should occur as early as possible in the assessment process - ideally within the planning stage and before construction commences. Project-affected communities should be included in decision-making. Financial institutions and their clients have to make sure that the voices of local stakeholders are heard and that the interests and needs of disadvantaged, vulnerable and marginalised groups are taken into consideration. The whole stakeholder engagement process should be free from external manipulation,

66 The UN Guiding Principles on Business and Human Rights is the first global standard for preventing and addressing the risk of adverse impacts on human rights linked to business activities. It encompass three principles: 1. "the state duty to protect against human rights abuses committed by third parties, including business, through appropriate policies, regulation and adjudication", 2. "the corporate responsibility to respect human rights [...] acting with due diligence to avoid infringing on the rights of others, and addressing harms that do occur" (i.e., need for a human rights due diligence process that enables corporations to be aware of, prevent, and address their adverse human rights impacts), and 3. "access by victims to effective remedy [...] through judicial, administrative, legislative or other appropriate means" (United Nations 2011b; cp. UN 2011a).

${ }^{67}$ A huge problem in this regard that has to be tackled is the problem of illiteracy in developing countries. 
interference, coercion and intimidation. Projects with adverse impacts on indigenous peoples even require their "Free, Prior and Informed Consent" (FPIC). It should be noted that FPIC does not create any veto rights nor does it require unanimity; however, it strives for consensus-building and thus goes beyond the previous EP II-consultation paradigm. 68

The EPs, in theory, go beyond the pure shareholder value approach. They try to incorporate multiple stakeholder perspectives including those of projectaffected communities, NGOs, civil society organisations and other stakeholder groups. The aim is dialogue between these groups, EPFIs and their clients. As such, the EPs ideally take a bottom-up approach that enhances democratic legitimacy. Stakeholder dialogue, public discourse and deliberation can be seen here as a source of organisational legitimacy. 69 The Principles also allow (multinational) companies to adapt to the changing community expectations of corporate responsibilities and help to reframe their public identity as corporate citizens - going beyond pure profit-seeking entities. 70

The protection of human rights - together with environmental protection and the fight against global warming/climate change - is, thus, at the heart of the third generation of the EPs. It is remarkable that it took exactly 10 years until the term "human rights" was introduced into the EP framework for the first time. Only the latest version of the EPs contains direct references to corporate human rights policy and corporate human rights due diligence. ${ }^{71}$ As such, EP III has to be

68 This idea of inclusion (in the sense of Teilhabe and integration) bears some remarkable resemblances to the works of the Nobel Prize laureates Amartya Sen (2009) and Elinor Ostrom (1990) as well as to Kantian philosophy - including Kant's notion of positive freedom, autonomy, human dignity and the Categorical Imperative which demands that people are treated as ends in themselves and never merely as means to an end (cp. Kant 1797/2013; 1785/2002; 1781/2011).

69 Haack et al. (2010: 33) speak of "legitimation as deliberation" and the "communicative sources of legitimation"; see also Scherer/Palazzo's (2007) interpretation of Habermasian discourse theory.

70 Cp. Wright/Rwabizambuga 2006: 92; Andrew 2009: 302; Matten/Crane 2005; Moon et al. 2005.

71 Human rights due diligence requires: (1) the development of a human rights policy statement; (2) periodic assessments and reports of actual and potential adverse human rights impacts of corporations' activities and (stakeholder) relationships; (3) the integration of commitments and assessments into internal control and monitoring systems, and; (4) reporting and tracking of human rights performance (cp. Torrance 2012). 
considered a major step forward compared to EP II with regards to (environmental protection and) human rights. But the current version of the EPs needs to be improved: There is only one explicit reference to the PRR-framework in a footnote. The term "human rights" is mentioned mainly in the preamble and the exhibit; the term "human rights due diligence" is mentioned only once and with the addition of "may be appropriate", while the terms "Human Rights Impact Assessment (HRIA)" and "human rights action plan" are lacking. EP III refers only once to gender issues and/or women's rights - in exhibit II. 72

Ruggie's (and the EPs') "human rights minimalism” (Wettstein 2012a: 745) poses serious problems: the Special Representative of the UN Secretary General on the issue of business and human rights (and the EPs) clearly favour an impactbased concept of negative corporate responsibility according to the motto "do no harm", that is, avoid causing or contributing to human rights violations. Ruggie (and therefore also the EPs) reject all forms of positive and leverage-based CSR. ${ }^{73}$ States are considered to be the primary duty bearers: According to Ruggie, international human rights laws apply only to states, but not to non-state actors such as (trans- or multinational) corporations. Thus, any duty to protect and realise human rights is part of the exclusive domain of nation-states (ie, nationstate centred perspectives). Corporations only need to fulfil the duty to respect human rights; exercising leverage to protect and realise human rights is regarded as an optional matter, not as a moral obligation. 74

The problem is that Ruggie's human rights "voluntarism" clashes with the fundamental moral nature of human rights. Human rights (including social and economic rights) are moral rights or entitlements that are deeply rooted in human dignity and the moral equality of all human beings. ${ }^{75}$ They are inalienable and universal moral rights that exist a priori and independently of nation-states and legal laws. This status of human rights rules out any form of moral discretion, arbitrariness and human rights voluntariness. Thus, (multinational) corporations have direct moral obligations unconditionally to respect, protect AND realise human rights. They are direct duty-bearers - in other words: states are not the exclusive and only bearers of positive obligations. Multinational corporations'

${ }^{72}$ Principles 7 and 9 (on independent review and monitoring) as well as principles 9 and 10 (on reporting) can be easily combined, thus creating space for a separate principle solely devoted to human rights issues. This principle should then precede all others and serve as an anchoring or guiding principle (cp. BankTrack 2012: 11; 2011: 16).

73 Cp. Wood 2011a; 2011b; 2012.

74 Cp. Ruggie 2007; 2008; 2009; 2013.

75 Cp. Wettstein 2009a; 2009b; 2010a; 2010b; 2012a; 2012b; Wettstein/Waddock 2005. 
moral responsibilities must go beyond "do no harm", and they must do more than merely respect human rights. Their scope of responsibility includes a positive duty to protect and realise human rights. Due to their political role and power (ie, transnational corporations as political, quasi-governmental actors, de facto rule

makers, addressees and authors of regulations 76 ), multinational corporations have a positive duty to speak out (ie, avoidance of corporate complicity defined as "aiding and abetting" in human rights violations committed by third parties), a duty to protect victims of human rights abuses, a duty to promote human rightscompatible institutions in home and host countries, and a duty to foster change or to put pressure on oppressive governments.

The EPA would be well advised to take the critique of Ruggie's PRRframework serious: What is needed is a push for non-voluntary, mandatory and legally binding rules for business in particular with respect to human rights as well as a comprehensive impact and leverage-based conception of responsibility (ie, making use of their leverage/organisation's capacity to influence other parties' decisions and activities, especially those which are part of the supply chain) including positive human rights obligations for corporations and a corporate human rights advocacy and activism.

\section{Conclusion}

This chapter has dealt with the special role of financial institutions as (de facto) "global sustainability regulators" (Conley/Williams 2011) 77 and standard setters in a transnational business context. 78 In many cases, these organisations

76 Cp. Scherer/Palazzo 2008; Scherer et al. 2009.

77 “... lenders, owing to their expertise in the project finance sector and their understanding of existing norms on managing environmental and social risk [...] are relatively well-placed to set effective standards and to effectively monitor their borrowers' conduct. [...] [yet] lenders are currently not well-placed to enforce the [EPs]. Their short-term interest in the completion of the projects they finance impairs their ability to credibly threaten to withdraw financing in the face of persistent non-compliance by borrowers" (cp. Sarro 2012: 1524).

78 This 'post-Westphalian world order' (Kobrin 2009) is characterised by the following characteristics: shift from government to governance (Foucault 2008); erosion of the regulatory power of the nation-state; fragmentation of legal-political authority and power; existence of regulatory or governance gaps; increasing ambiguity of borders and jurisdictions; blurring of the separation between private 
have taken the lead in fostering CSR and sustainable development, particularly in politically unstable and/or socially and environmentally fragile contexts such as developing countries and emerging markets. By introducing developed-country social and environmental standards into developing regions, they have adopted the role of quasi-regulators. ${ }^{79}$ Banks, insurance companies and the like are key factors in the transition towards a green economy. They ideally help to catalyse this process towards economic, ecological and social sustainability and CSR by voting with their money. 80

During this process, the EPs have an important function to fulfil: They ideally help to balance economic (profit), ecological (planet) and ethical issues (people) (so called "triple P" framework). They have the potential to equally promote selfinterest and the common good: EPFIs and clients pursue their own economic (pecuniary) motives 81 , while the adopted principles make sure that environmental, social and human rights standards are met.

The EPs have the ability to function as a catalyst for cultural change within banks. ${ }^{82}$ Yet, in order to fully do so, some necessary reform steps have to be adopted. According to Jeucken (2001/2002: 72), four types of banking have to be distinguished: defensive banking (“... environmental laws and regulations are thought to be threats to its business. Only curative measures are taken. In this vision, care for the environment only adds to costs and there is certainly no money to be earned from it"), preventive banking (“... different from the previous phase in that potential costs savings are identified. [...] A bank does not want to go any further than the environmental laws that exist [...] it is somewhat passive, limiting external risks and liabilities and saving production costs internally"), offensive banking ("Banks see new opportunities in the marketplace, both in the area of specific products and new markets [...]. The bank is looking for profitable, environmentally sound opportunities in the market, which can compete with alternative investment and lending opportunities. The stance can be described as proactive, creative and innovative [...]. The extra steps are taken whenever there are win-win situations at the micro-level..."), and sustainable banking ("... the bank lays down qualitative preconditions so that all its activities are sustainable

and public spheres; and politicization of non-state actors such as transnational corporations, civil society and non-governmental organisations (cp. Kobrin 2009: 5; see also Jessup 1956; Zumbansen 2006; 2010a; 2010b; Baur 2011: 21).

${ }^{79} \mathrm{Cp}$. Conley/Williams 2011.

${ }^{80} \mathrm{Cp}$. Conley/Williams 2011: 565.

${ }^{81}$ By reducing various forms of economic and non-economic risks, the EPs can also help to make a project a more secure investment and a safer loan.

${ }^{82} \mathrm{Cp}$. Conley/Williams 2011: 546. Whether such a change in organisational culture has already started remains doubtful as recent financial market crises, the EURIBOR and LIBOR scandals and other corporate governance scandals (especially in the investment banking sector) have shown. 
$[\ldots]$ thanks to a consciously chosen policy [...] [and] the ambition to operate sustainably in every respect"). EPFIs fall either into the preventive or offensive type of banking category where a holistic and all-encompassing implementation of the spirit of the EPs is still lacking. What is required from an economic ethics perspective is the transformation from preventive/offensive banking towards sustainable banking. This implies that the spirit of the EPs needs to be embedded throughout the whole organisation. All levels of the organisation should internalise the spirit of the EPs. Environmental and social risk management as well as CSR due diligence should ideally be integrated into the company's core businesses. Recruitment, staff and front-line training as well as awareness and consciousness rising and sensitising are also essential. Of eminent importance is the top-level commitment: The CEO and other senior managers function as rolemodels. A change in organisational culture (towards the ideal of the honourable (banking) merchant) also affects the incentive structures and in particular the bonus payment systems or compensation structures/packages that should be longrather than short-term oriented. So far, investment managers are judged according to their quarterly or annual performance and not according to their multiple-years performance. 83

In order to further strengthen the EPs as a true benchmark for responsible investment practices this paper has identified the following 10 necessary reform steps (ie, top 10 priorities towards EP IV ${ }^{84}$ ):

\section{Necessary Reform Steps}

1. Introduction of an anchoring and guiding principle solely devoted to human rights;

2. Extension of scope I: The spirit of the EPs should be applied to all banking activities (including investment banking) and not being restricted to project finance alone ('going beyond project finance');

${ }^{83}$ Cp. Chan 2012: 1345.

84 EP III has to be considered as an improvement over EP II (cp. EPA 2006), but bigger steps must be taken by the EPFIs to further strengthen the EPs. Reform measures to fight global warming (climate change) and to fully realise corporate human rights responsibilities are important issues. Further fields of necessary reform include the extension of scope, an increase in transparency and accountability (see also BankTrack 2012). 
3. Extension of (regional) scope II: An outreach strategy to BRIC countries is required in order to guaranty world-wide application of the EPs;

4. Introduction of an enforcement pyramid including automatic sanctions like delisting and exclusion of non-compliant EPFIs;

5. Introduction of absolute performance standards, ie, clear, verifiable metrics that are transparently and independently monitored which help to assess environmental and social performance of EPFIs and their clients;

6. Introduction of minimum entry requirements that have to be met prior becoming a member of the EPA (eg, human rights due diligence; grievance/complaint and remedy mechanisms);

7. Tiered membership structure within the EPA that allows to bridge the gap between broadening and deepening considerations;

8. Reform of the EPA including enhanced funding and staffing, establishment of an EP-Forum and an EPs' advisory group as well as establishment of an EPombudsman office;

9. Establishment of third-party beneficiary rights for project-affected communities;

10.Regulatory Pressure: Stronger government oversight (including binding/mandatory regulation) should be accompanied by increasing shareholder pressure (ie, divestment from companies which violate social, environmental and human rights standards; shareholders filing lawsuits against CEOs and senior management) and market regulation pressure (ie, denied market access by securities and exchange commissions; exclusion of companies from sustainability indexes).

Given that these reform steps are implemented in the near future (which imply a reform of the Governance Rules ${ }^{85}$ as well), the EP framework can be seen as the starting point of developing hard(er) law through soft law (ie, hardening of transnational norms). ${ }^{86}$ The EPs have to be considered as an essential step forward in an unregulated and potentially destructive area of doing business, but they require further strengthening, especially strengthening of the governance system (ie, enforcement, monitoring and sanctioning mechanisms) in order to enhance transparency, accountability and liability.

\section{References}

ANDREW, Jane (2009): Responsible Finance? The Equator Principles and Bank Disclosures; The Journal of American Academy Business 14(2); 302-307.

BANKTRACK (2011): The Outside Job. Turning the Equator Principles towards people and planet; www.banktrack.org/show/pages/equator_principles (accessed 11 July 2013).

- (2012): Tiny steps forward on the Outside Job. Comments on the Equator Principles III Official First Draft; www.banktrack.org/show/pages/equator_principles\#tab_pages_documents (accessed 11 July 2013).

\footnotetext{
${ }^{85}$ Cp. EPA 2010.

${ }^{86}$ Cp. Conley/Williams 2011: 565.
} 
- (2013): BankTrack on the Thun Group Paper on Banks and Human Rights; available at: http://www.banktrack.org/download/banktrack_on_the_thun_group_paper_on_banks_and_hu man_rights/banktrack_thun_group_paper_131119_0.pdf (accessed: 8 January 2014).

BAUR, Dorothea (2011): NGOs as Legitimate Partners of Corporations. A Political Conceptualization; Dordrecht, Springer.

CHAN, Matthew (2012): What About Psychological Actors? Behavioral Analysis of Equator Principle Adoption and its Implications; German Law Journal 13(12); 1339-1362.

CONLEY, John M./WILLIAMS, Cynthia A. (2011): Global Banks as Global Sustainability Regulators? The Equator Principles; Law and Policy 33(4); 542-575.

EQUATOR PRINCIPLES (2006): The "Equator Principles" (EP II); available at: http://equatorprinciples.com/index.php/ep3/ep3 (accessed 11 July 2013).

- (2010): Governance Rules; available at: www.equator-

principles.com/index.php/about/governance-and-management (accessed 11 November 2013).

- (2011): Guidance Note on Equator Principles Implementation Reporting; available at: http://equator-principles.com/index.php/reporting-requirements (accessed 11 November 2013).

- (2013a): The Equator Principles (EP III); available at: http://equatorprinciples.com/index.php/ep3/ep3 (accessed 11 November 2013).

- (2013b): Equator Principles Website; available at: www.equator-principles.com/ (accessed 8 January 2014).

FACING FINANCE (2012): Dirty Profits I. Report on Companies and Financial Institutions Benefiting from Violations of Human Rights; available at: http://www.facing-finance.org/wpcontent/blogs.dir/16/files/2012/12/ff_dirtyprofits.pdf (accessed 8 January 2014).

- (2013): Dirty Profits II. Report on Companies and Financial Institutions Benefiting from Violations of Human Rights; available at: http://www.facingfinance.org/files/2013/12/DIRTY_PROFITS_II.pdf (accessed 8 January 2014).

FLOHR, Anne (2014): A Complaint Mechanism for the Equator Principles - and Why Equator Members should urgently want it; forthcoming in: Transnational Legal Theory.

FOUCAULT, Michel (2008): The Birth of Biopolitics. Lectures at the Collège de France 19781979; Houndmills; Palgrave Macmillan.

HAACK, Patrick/SCHOENEBORN, Dennis/WICKERT, Christopher (2010): Exploring the Constitutive Conditions for a Self-Energizing Effect of CSR Standards: The Case of the "Equator Principles"; Working Paper Series Institute of Organization and Administrative Science, University of Zurich No. 115.

HARDENBROOK, Andrew (2007): The Equator Principles: The Private Financial Sector's Attempt at Environmental Responsibility; Vanderbilt Journal of Transnational Law 40; 197 232.

IMAI, Shin/ MEHRANVAR, Ladan/SANDER, Jennifer (2007): Breaching Indigenous Law: Canadian Mining in Guatemala; Indigenous Law Journal 6(1); 101-139.

IMAI, Shin/MAHEANDIRAN, Bernadette/CRYSTAL, Valerie (2012): Accountability Across Borders: Mining in Guatemala and the Canadian Justice System; Osgoode CLPE Research Paper 26/2012; available at: http://papers.ssrn.com/sol3/papers.cfm?abstract_id=2143679 (accessed 31 July 2013).

INTERNATIONAL FINANCE CORPORATION (2012a): Performance Standards on Environmental and Social Sustainability; available at:

www.ifc.org/wps/wcm/connect/Topics_Ext_Content/IFC_External_Corporate_Site/IFC+Sustain ability/Sustainability+Framework/Sustainability+Framework++2012/Performance+Standards+and+Guidance+Notes+2012/ (accessed 11 July 2013).

- (2012b): Guidance Notes: Performance Standards on Environmental and Social Sustainability; available at:

http://www.ifc.org/wps/wcm/connect/e280ef804a0256609709ffd1a5d13d27/GN_English_20 12_Full-Document.pdf?MOD=AJPERES (accessed 30 November 2013). 
INTERNATIONAL FINANCE CORPORATION COMPLIANCE ADVISOR OMBUDSMAN (2013): CAO Annual Report 2013; available at: http://www.caoombudsman.org/publications/documents/CAO_AR13_ENG_high.pdf (accessed: 11 November 2013).

JESSUP, Philip (1956): Transnational Law, New Haven, Yale University Press.

JEUCKEN, Marcel (2001/2002): Sustainable Finance and Banking: The Financial Sector and the Future of the Planet; London, Earthscan Publications.

KANT, Immanuel (1781/2011): The Critique of Pure Reason; London, Penguin Classics.

- (1785/2002): Groundwork for the Metaphysics of Morals; New Haven, Yale University Press.

- (1797/2013): The Metaphysics of Morals; Cambridge, Cambridge University Press.

KOBRIN, Stephen J. (2009): Private Political Authority and Public Responsibility: Transnational Politics, Transnational Firms and Human Rights; Business Ethics Quarterly 19(3); 349-374.

KULKARNI, Parashar (2010): Pushing Lenders to Over-Comply with Environmental Regulations: A Developing Country Perspective; Journal of International Development 22; 470-482.

LAZARUS, Suellen (2014): The Equator Principles at Ten Years; forthcoming in: Transnational Legal Theory.

LAZARUS, Suellen/FELDBAUM, Alan (2011): Equator Principles Strategic Review. Final Report; available at: www.equator-principles.com/resources/execsummary_appendix_strategic_review_report.pdf (accessed 11 July 2013).

LEE, Vivian (2008): Enforcing the Equator Principles: An NGO's Principled Effort to Stop the Financing of a Paper Pulp Mill in Uruguay; Northwestern Journal of International Human Rights 6(2); 354-373.

MACVE, Richard/CHEN, Xiaoli (2010): The "equator principles": a success for voluntary codes?; Accounting, Auditing \& Accountability Journal 23(7); 890-919.

MARCO, Marissa (2011): Accountability in International Project Finance: The Equator Principles and the Creation of Third-Party-Beneficiary Status for Project-Affected Communities; Fordham International Law Journal 34(3); 452-503.

MATTEN, Dirk/CRANE, Andrew (2005): Corporate Citizenship: Towards and extended theoretical conceptualization; The Academy of Management Review 30(1); 166-179.

MEYERSTEIN, Ariel (2013): Global Private Regulation in Development Finance: The Equator Principles and the Transnationalization of Public Contracting in: Mathias Audit/Stephan Schill (eds.): The Internationalization of Public Contracts; Bruylant; 1-41.

MIKADZE, Kirsten (2012): Public Participation in Global Environmental Governance and the Equator Principles: Potential and Pitfalls; German Law Journal 13(12); 1386-1411.

MOON, Jeremy/CRANE, Andrew/MATTEN, Dirk (2005): Can Corporations be Citizens? Corporate Citizenship as a Metaphor for Business Participation in Society; Business Ethics Quarterly 15(3); 429-453.

NWETE, Bede O.N. (2005): The Equator Principles: How far will it affect Project Financing? International Business Law Journal 2; 173-188.

OSTROM, Elinor (1990): Governing the Commons. The evolution of institutions for collective actions; Cambridge, Cambridge University Press.

O'SULLIVAN, Niamh/O'DWYER, Brendan (2009): Stakeholder perspectives on a financial sector legitimation process. The case of NGOs and the Equator Principles; Accounting, Auditing \& Accountability Journal 22(4); 553-587.

RICHARDSON, Benjamin J. (2005): The Equator Principles: The Voluntary Approach to Environmentally Sustainable Finance; European Environmental Law Review November 2005; 280-290.

RUGGIE, John Gerard (2007): Business and Human Rights: Mapping International Standards of Responsibility and Accountability for Corporate Acts. Report of the Special Representative of the Secretary-General (SRSG) on the issue of human rights and transnational corporations and other business enterprises; A/HRC/4/035; available at: www.businesshumanrights.org/Documents/RuggieHRC2007 (accessed 8 October 2013). 
- (2008): Protect, Respect and Remedy. A Framework for Business and Human Rights. Report of the Special Representative of the United Nations Secretary-General on the issue of human rights and transnational corporations and other business enterprises; Innovations: Technology, Governance, Globalization 3(2); 189-212; available at: www.mitpressjournals.org/doi/pdfplus/10.1162/itgg.2008.3.2.189 (accessed 8 October 2013).

- (2009): Business and Human Rights: Towards Operationalizing the "Protect, Respect and Remedy" Framework. Report of the Special Representative of the Secretary-General on the Issue of Human Rights and Transnational Corporations and Other Business Enterprises; A/HRC/11/13; available at: www.refworld.org/docid/49faf98a2.html (accessed 8 October 2013).

- (2013): Just Business. Multinational Corporations and Human Rights; W.W. Norton \& Company, New York.

SARRO, Douglas (2012): Do Lenders Make Effective Regulators? An Assessment of the Equator Principles on Project Finance; German Law Journal 13(12); 1522-1555.

SCHEPERS, Donald H. (2011): The Equator Principles: a promise in progress? Corporate Governance 11(1); 90-106.

SCHERER, Andreas Georg/PALAZZO, Guido (2007): Toward a Political Conception of Corporate Responsibility - Business and Society seen from a Habermasian Perspective; Academy of Management Review 32; 1096-1120.

SCHERER, Andreas Georg/PALAZZO, Guido (2008): Globalization and Corporate Social Responsibility in: A. Crane/A. McWilliams/D. Matten/J. Moon/D. Siegel (eds.): The Oxford Handbook of Corporate Social Responsibility; Oxford, Oxford University Press; 413-431.

SCHERER, Andreas Georg/PALAZZO, Guido/MATTEN, Dirk (2009): Introduction to the Special Issue: Globalization as a Challenge for Business Responsibilities; Business Ethics Quarterly 19(3); 327-347.

SCHOLTENS, Bert/DAM, Lammertjan (2007): Banking on the Equator. Are Banks that Adopted the Equator Principles Different from Non-Adopters; World Development 35(8); 1307-1328

SEN, Amartya (2009): The Idea of Justice; Cambridge, Harvard University Press.

SUPREME COURT OF CANADA (2013): Judgments of the Supreme Court of Canada: Ezokola v. Canada; available at: http://scc.lexum.org/decisia-scc-csc/scc-csc/scccsc/en/item/13184/index.do (accessed 25 July 2013).

THOMSON REUTERS (2012): Project Finance Review Full Year 2012; available at: http://dmi.thomsonreuters.com/Content/Files/Q42012_Project_Finance_Review.pdf (accessed: 11 November 2013).

THUN GROUP OF BANKS (2013): UN Guiding Principles on Business and Human Rights. Discussion Paper for Banks on Implications of Principles 16-21; available at: www.csrandthelaw.com/wp-content/uploads/2013/10/thun_group_discussion_paper.pdf (accessed 8 January 2014).

TORRANCE, Michael (ed.) (2012): Human Rights in: Michael Torrance (ed.): IFC Performance Standards on Environmental and Social Sustainability. A Guidebook; Markham, LexisNexis Canada; 317-334.

UNITED NATIONS (2011a): The UN “Protect, Respect and Remedy" Framework for Business and Human Rights; available at: www.businesshumanrights.org/SpecialRepPortal/Home/Protect-Respect-RemedyFramework/GuidingPrinciples (accessed 11 July 2013).

- (2011b): Guiding Principles on Business and Human Rights; available at: www.ohchr.org/Documents/Publications/GuidingPrinciplesBusinessHR_EN.pdf (accessed 11 July 2013).

WETTSTEIN, Florian (2009a): Multinational Corporations and Global Justice. Human Rights Obligations of a Quasi-Governmental Institution; Stanford, Stanford University Press.

- (2009b): Beyond Voluntariness, Beyond CSR: Making a Case for Human Rights and Justice; Business and Society Review 114(1); 125-152. 
- (2010a): The Duty to Protect: Corporate Complicity, Political Responsibility, and Human Rights Advocacy; Journal of Business Ethics 96; 33-47.

- (2010b): For Better or For Worse: Corporate Responsibility Beyond "Do No Harm"; Business Ethics Quarterly 20(2); 275-283.

- (2012a): Silence as Complicity: Elements of a Corporate Duty to Speak Out against the Violation of Human Rights; Business Ethics Quarterly 22(1); 37-61.

- (2012b): CSR and the Debate on Business and Human Rights: Bridging the Great Divide; Business Ethics Quarterly 22(4); 739-770.

WETTSTEIN, Florian/WADDOCK, Sandra (2005): Voluntary or Mandatory: That is (Not) the Question. Linking Corporate Citizenship to Human Rights Obligations for Business; Zeitschrift für Wirtschafts- und Unternehmensethik zfwu 6(3); 304-320.

WOOD, Stepan (2003a): Environmental Management Systems and Public Authorities in Canada: Rethinking Environmental Governance; Buffalo Environmental Law Journal 10; 129-210.

- (2003b): Green Revolution or Greenwash? Voluntary Environmental Standards, Public Law, and Private Authority in Canada, in: Law Commission of Canada (ed.): New Perspectives on the Public-Private Divide; Vancouver/Toronto, UBC Press; 123-165.

- (2011a): Four Varieties of Social Responsibility: Making Sense of the "Sphere of Influence" and "Leverage" Debate via the Case of ISO 26000; Osgoode Hall Law School Comparative Research in Law and Political Economy 07(04); available at: http://papers.ssrn.com/sol3/papers.cfm?abstract_id=1777505 (accessed 8 October 2013).

- (2011b): The Meaning of 'Sphere of Influence' in ISO 26000 in: Adrian Henriques (ed.): Understanding ISO 26000: A Practical Approach to Social Responsibility; London, BSI; 115 130.

- (2012): The Case for Leverage-Based Corporate Human Rights Responsibility; Business Ethics Quarterly 22(1); 63-98.

WOOD, Stepan/JOHANNSON, Lynn (2008): Principles for Integrating Non-Governmental Environmental Standards into Smart Regulation, Osgoode Hall Law Journal 46; 345-395.

WRIGHT, Christopher (2012): Global Banks, the Environment, and Human Rights: The Impact of the Equator Principles on Lending Policies and Practices, Global Environmental Politics $12 ; 56-77$.

WRIGHT, Christopher/RWABIZAMBUGA, Alexis (2006): Institutional Pressure, Corporate Reputation, and Voluntary Codes of Conduct: An Examination of the Equator Principles; Business and Society Review 111(1); 89-117.

ZUMBANSEN, Peer (2004): Globalization and the Law: Deciphering the Message of Transnational Human Rights Litigation; German Law Journal 5(12); 1499-1520.

- (2005): Beyond Territoriality: The Case of Transnational Human Rights Litigation, 4 Constitutionalism Web-Papers 4/2005 (2005), available at: www.wiso.unihamburg.de/fileadmin/sowi/politik/governance/ConWeb_Papers/conweb4-2005.pdf (accessed 31 July 2013);

- (2006): Transnational Law; in: Jan Smits (ed.): Encyclopedia of Comparative Law; Edward Elgar Publishing; 738-754.

- (2010a): Neither 'Public' nor 'Private', 'National' nor 'International'. Transnational Corporate Governance from a Legal Pluralist Perspective; Osgoode Hall Law School Comparative Research in Law \& Political Economy, Research Paper Series, Research Paper 22/2010; available at: http://papers.ssrn.com/sol3/papers.cfm?abstract_id=1626338 (accessed 31 July 2013).

- (2010b): Transnational Legal Pluralism; Transnational Legal Theory 1(2); 141-189. 